\title{
Forage Feeding to Reduce Preharvest Escherichia coli Populations in Cattle, a Review
}

\author{
T. R. Callaway, ${ }^{\star}$ R. O. Elder, ${ }^{\star}$ J. E. Keen,† R. C. Anderson, ${ }^{\star}$ and D. J. Nisbet ${ }^{\star 1}$ \\ ${ }^{*}$ Food and Feed Safety Research Unit, Southern Plains Agricultural Research Center, \\ Agricultural Research Service, USDA, \\ College Station, TX 77845, USA \\ †Meat Animal Research Center \\ Clay Center, NE
}

\section{ABSTRACT}

Although Escherichia coli are commensal organisms that reside within the host gut, some pathogenic strains of $E$. coli can cause hemorrhagic colitis in humans. The most notable enterohemorrhagic $E$. coli (EHEC) strain is O157:H7. Cattle are asymptomatic natural reservoirs of $E$. coli $\mathrm{O} 157: \mathrm{H} 7$, and it has been reported that as many as $30 \%$ of all cattle are carriers of this pathogen, and in some circumstances this can be as high as $80 \%$. Feedlot and high-producing dairy cattle are fed large grain rations in order to increase feed efficiency. When cattle are fed large grain rations, some starch escapes ruminal microbial degradation and passes to the hindgut where it is fermented. EHEC are capable of fermenting sugars released from starch breakdown in the colon, and populations of $E$. coli have been shown to be higher in grain fed cattle, and this has been correlated with $E$. coli O157:H7 shedding in barley fed cattle. When cattle were abruptly switched from a high grain (corn) diet to a forage diet, generic $E$. coli populations declined 1000-fold within $5 \mathrm{~d}$, and the ability of the fecal generic $E$. coli population to survive an acid shock similar to the human gastric stomach decreased. Other researchers have shown that a switch from grain to hay caused a smaller decrease in $E$. coli populations, but did not observe the same effect on gastric shock survivability. In a study that used cattle naturally infected with $E$. coli O157:H7, fewer cattle shed $E$. coli O157:H7 when switched from a feedlot ration to a forage-based diet compared with cattle continuously fed a feedlot ration. Results indicate that switching cattle from grain to forage could potentially reduce EHEC populations

Received January 31, 2002.

Accepted February 21, 2002.

Corresponding author: T. R. Callaway; e-mail: callaway@ffsru. tamu.edu.

${ }^{1}$ Proprietary or brand names are necessary to report factually on available data; however, the USDA neither guarantees nor warrants the standard of the product, and the use of the name by the USDA implies no approval of the product, and exclusion of others that may be suitable. in cattle prior to slaughter; however the economic impact of this needs to be examined.

(Key words: Escherichia coli, cattle, forage, feeding)

Abbreviation key: EHEC = enterohaemorrhagic $E$. coli, HUS = hemolytic uremic syndrome, IMS = immunomagnetic bead separation.

\section{INTRODUCTION}

Escherichia coli is a facultative anaerobic bacterium that is a normal inhabitant of the mammalian intestinal tract (Drasar, 1974). Many E. coli strains are harmless or even beneficial to the host; however, some strains of $E$. coli can be pathogenic to humans and can be harbored within food animals. Although several E. coli strains (e.g., O111, O26) can cause hemorrhagic colitis in humans, E. coli O157:H7 is the best known enterohemorrhagic E. coli (EHEC) strain. Escherichia coli O157:H7 causes over 73,000 illnesses in the United States each year and approximately 60 deaths (Mead et al., 1999). Enterohemorrhagic E. coli infections are estimated to cost the US economy approximately $\$ 1$ billion per year (USDA:ERS, 2001).

The most frequently implicated vector for $E$. coli O157:H7 outbreaks has been ground beef, and bovinederived products have been linked to approximately $75 \%$ of outbreaks (USDA:APHIS, 1997). It is now widely accepted that ruminants are natural reservoirs of EHEC (including E. coli O157:H7) (Chapman et al., 1993; Rasmussen et al., 1993; Armstrong et al., 1996). Repeated outbreaks of hemorrhagic colitis linked to ground beef and/or cattle manure has firmly established the connection between cattle and E. coli $\mathrm{O} 157: \mathrm{H} 7$ in the public mind. Repeated large-scale recalls of contaminated ground beef, and the deaths of children who consumed foods contaminated by exposure to meat products have further shaken the confidence of consumers in the wholesomeness and safety of beef.

Sanitation efforts after slaughter reduce contamination of carcasses with $E$. coli O157:H7 (Elder et al., 2000); however, these efforts are not necessarily 
enough. Approximately $30 \%$ of all cattle are asymptomatic carriers of $E$. coli O157:H7 (Elder et al., 2000). Therefore, methods that focus on reducing $E$. coli O157:H7 populations in food animals before entry to the food chain have the potential to reduce human illnesses. This review examines the effects of dietary manipulations on $E$. coli populations in cattle.

\section{DISCUSSION}

\section{Enterohaemorrhagic E. coli as a Food-Borne Pathogen}

Escherichia coli O157:H7 was first isolated during a fatal outbreak of bloody diarrhea (hemorrhagic colitis) in 1982 caused by improperly cooked hamburger meat (Riley et al., 1983). In recent years there have been repeated outbreaks of hemorrhagic colitis in humans (Doyle et al., 1997) and, in fact, E. coli O157:H7 infection in humans has become known as "hamburger disease," "barbecue season syndrome," or in some alarmist circles, "feedlot disease" (Martens, 2000). Even though E. coli O157:H7 is only one of several strains of EHEC, it is responsible for most of the large-scale outbreaks in the United States (O'Brien and Kaper, 1998).

The impact of EHEC on the human intestinal tract is profound. Escherichia coli O157:H7 tightly binds the bacterium to the intestinal epithelial surface and produces "attaching and effacing" lesions (Kaper et al., 1998). Enterohemorrhagic $E$. coli strains produce toxins homologous to the toxins of Shigella dysenteriae and are therefore also interchangeably known as shiga toxinproducing or verotoxin-producing $E$. coli (STEC or VTEC, respectively) (Mainil, 1999). Shiga toxins inhibit protein synthesis in the intestinal epithelium producing bloody diarrhea (Su and Brandt, 1995). Shiga toxins that cross the epithelium can reach the bloodstream and eventually the kidneys and induce a condition in humans known as hemolytic uremic syndrome (HUS) (Griffin, 1998). Approximately 5\% of the cases of $E$. coli O157:H7 hemorrhagic colitis progress to the level of HUS, which can include severe kidney damage or complete renal failure and can become life threatening, especially in children and the elderly (Mead et al., 1999). The CDC conservatively estimates 3000 cases of HUS, and at least 60 deaths each year are attributable to $E$. coli O157:H7 in the United States (Mead et al., 1999).

\section{Gastric Shock Survival}

The gastric stomach serves as a barrier to intestinal colonization by pathogenic bacteria because of its low $\mathrm{pH}$ and enzymatic activity (Waterman and Small, 1998). However, some bacteria are able to survive gas- tric passage. Bacteria that are more resistant to the gastric environment therefore have a greater opportunity to survive and to ultimately colonize the intestinal tract and cause illness. The infectious dose is indicative of the virulence of pathogenic bacteria, and $E$. coli O157:H7 has an extremely low infectious dose. In one outbreak, the contamination level of $E$. coli $\mathrm{O} 157: \mathrm{H} 7$ in uncooked hamburger meat was less than 700 cells/ patty and some victims ingested very little of the (improperly) cooked meat (Griffin, 1998). In another outbreak the infectious dose of O157:H7 was less than 50 cells (Tilden et al., 1996), and for the EHEC O111, less than 1 cell/10 $\mathrm{g}$ of salami was sufficient to induce hemorrhagic colitis (Paton et al., 1996). Because such a low number of cells are capable of causing illness, the capacity of $E$. coli $\mathrm{O} 157: \mathrm{H} 7$ to survive gastric exposure directly impacts its ability to cause illness.

Diez Gonzalez et al. (1998) reported that grain-feeding greatly increased the acid resistance of $E$. coli in cattle, but some workers have challenged this conclusion (Hovde et al., 1999). Indeed, Hovde et al. (1999) concluded that diet was without effect. This contradiction may be at least partially explained by the use of different in vitro methods of cultivation. If $E$. coli are cultivated in the lab in a rich medium before acid shock, acid resistance is induced by amino acids, and it is impossible to detect a diet difference (Jarvis and Russell, 2001). Confusion has also arisen regarding the definition of acid resistance; some of this debate can be attributed to confusion over the terminology "acid resistance" which has been used interchangeably to describe both growth at acidic $\mathrm{pH}$, as well as the ability to survive an acid (gastric) shock. Lin et al. (1996) suggested that a term to describe survival after an acid (gastric) shock should be "extreme acid resistance." In some cases, differences between reports can be attributed to different acid shock methodologies (e.g., differences in shock $\mathrm{pH}$, length of shock time, etc.) and others can be considered artifacts of culture growth methods and recovery media (Diez-Gonzalez et al., 1998; Hovde et al., 1999; Jarvis and Russell, 2001). The use of different acid shock culture methodologies makes direct comparisons between the studies of Hovde et al. (1999) and Russell et al. difficult (Jarvis and Russell, 2001). Because the ability to survive gastric passage is critical to the virulence of $E$. coli O157:H7, factors that impact the development of "extreme acid resistance" are important to reducing human illness and need to be elucidated through the use of a standardized acid shock methodology.

\section{Cattle as Reservoirs of Enterohaemorrhagic E. coli}

Ruminant animals are populated by a microbial consortium that allows the animal to convert cellulosic 
forages to high quality meat, milk, or fiber (Hungate, 1966). It is well known that ruminants (both domestic and wild) can be asymptomatic reservoirs of EHEC (Wells et al., 1991; Hancock et al., 1994; Bielaszewska et al., 2000). The microbial population of the ruminant is very diverse and microbes are found throughout the reticulorumen, as well as the intestinal tract. Because the gastrointestinal tract is well suited for microbial growth it is no surprise that the ubiquitous and adaptable $E$. coli (represented by many strains, including EHEC) lives in the gut of mammals, including cattle and humans (Drasar and Barrow, 1985).

Escherichia coli are rarely cultured in high numbers from the rumen of cattle (less than $10^{6}$ cells $/ \mathrm{ml}$ out of a population of $10^{10}$ cell $\mathrm{s} / \mathrm{ml}$ ) (Wolin, 1969) and are found at concentrations from $10^{2}$ to $10^{7}$ cells/g of feces at slaughter (Davidson and Taylor, 1978). Escherichia coli have rarely been considered important members of the ruminal microbial ecosystem due to the toxicity of high ruminal concentrations of VFA and competition for available nutrients (Wolin, 1969). However, this sensitivity of $E$. coli to VFA is strain specific and can be linked to the use of strains maintained in vitro for long periods of time; several nonlaboratory-adapted strains (fresh isolates) of $E$. coli are quite capable of growth in conditions similar to those found in the rumen (Diez Gonzalez and Russell, 1997). Even though E. coli strains comprise a larger proportion of the intestinal microbial population (up to $1 \%$ ), E. coli counts are highly variable and are still outnumbered by the strictly anaerobic bacterial population (Davidson and Taylor, 1978; Drasar and Barrow, 1985; Diez-Gonzalez et al., 1998). Enterohemorrhagic $E$. coli strains are very rarely the predominant strains of $E$. coli found in the rumen or intestine. Although other EHEC strains responsible for human illnesses have been isolated from cattle (e.g., O111, O136) (Midgley et al., 1999; Hornitzky et al., 2000), most surveys in cattle have primarily measured O157:H7 (Hancock et al., 1994, 1998). Recently, however, Acheson (2000) has emphasized that surveys should examine the prevalence of all EHEC rather than certain species.

Cattle are not known to express receptors for Shiga toxins and do not suffer from hemorrhagic diarrhea when infected with EHEC (Pruimboom-Brees et al., 2000). Therefore it is impossible to visually identify "sick" animals. Even though cattle have been shown to be a reservoir for $E$. coli O157:H7 (Wells et al., 1991; Rasmussen et al., 1993), it has been thought that the colonization by EHEC is transient (Hancock et al., 1998). Detection of E. coli O157:H7 in the live animal has been hampered because studies have used enrichment culture followed by direct plate counting, which has a very low sensitivity (Buchko et al., 2000a). Even with the use of more sophisticated molecular detection methods, shedding of EHEC still appears sporadic. Estimates of $E$. coli $\mathrm{O} 157: \mathrm{H} 7$ and EHEC populations using molecular techniques and immunomagnetic bead separation (IMS) demonstrated an E. coli O157:H7 incidence of up to 100-fold greater than previously reported by use of culture-based enrichment techniques (Chapman et al., 1997a, 1997b; Mechie et al., 1997; Buchko et al., 2000a).

Whereas the majority of the epidemiological data collected on EHEC in cattle was gathered using less sensitive culture-based techniques, these studies provide important information on factors that affect the prevalence of $E$. coli $\mathrm{O} 157: \mathrm{H} 7$. The prevalence of $E$. coli O157:H7 in cattle was found to vary widely in culturebased several surveys, but is highly dependent on cattle age and season (USDA:APHIS, 1997; Zhao et al., 1995). Calves shed more E. coli O157:H7 cells and for longer periods of time than did adult cows (Zhao et al., 1995; Mechie et al., 1997). Periparturient cows demonstrated increased fecal shedding of coliform bacteria during the period immediately before and after calving (PelanMattocks et al., 2000). Escherichia coli O157:H7 populations in cattle vary throughout the year: as many as $80 \%$ of all feedlot cattle may be infected during the summer months, but as few as $10 \%$ may shed during the winter (Elder et al., 2000; R. O. Elder, unpublished data). This correlates with a rise in human outbreaks during each summer/early fall thus emphasizing a linkage between animal (reservoir) populations and human food-borne outbreaks. Surveys conducted throughout the United States indicated that the distribution of $E$. coli O157:H7 in cattle was not geographically linked (Dargatz et al., 1997; Hancock et al., 1997b); however, this appears to contradict a report that human outbreaks are more prevalent in the northern United States (Griffin, 1998).

Escherichia coli O157:H7 colonization appears to be widespread in both beef and dairy herds and is highly variable within each animal and herd; however, some herds appear to have higher shedding incidences than do others (USDA:APHIS, 1997; Hancock et al., 1998). The median percentage of $E$. coli $\mathrm{O} 157: \mathrm{H} 7$ positive animals in studies that used traditional culture techniques was estimated at $1.7 \%$ (Jackson et al., 1998). Other culture-based studies have indicated that $4 \%$ of cattle were colonized by up to 26 different serotypes of EHEC (Schurmann et al., 2000).

Until recently, it was thought that only 1 to $3 \%$ of cattle were carriers of $E$. coli $\mathrm{O} 157: \mathrm{H} 7$. However, the use of immunomagnetic bead separation (IMS) to identify $E$. coli $\mathrm{O} 157: \mathrm{H} 7$ in feces has steadily increased the accepted incidence value (Chapman et al., 1997a; Mechie et al., 1997). Researchers using IMS initially 
found that $16 \%$ of the animals tested in both beef and dairy herds were $E$. coli $\mathrm{O} 157: \mathrm{H} 7$ positive, and as many as $62 \%$ of dairy heifers were populated with $E$. coli O157:H7 (Mechie et al., 1997). Additional IMS studies in Europe indicated that 18, 32, and $75 \%$ of dairy cows, sheep, and goats, respectively (Zschöck et al., 2000), and $20 \%$ of feedlot cattle in the Czech Republic were EHEC carriers (Cizek et al., 1999). In the United States, Elder et al. (2000) demonstrated that $28 \%$ of all feedlot cattle contained $E$. coli $\mathrm{O} 157: \mathrm{H} 7$. More recent IMS studies have shown that approximately $50 \%$ of feedlot cattle harbor E. coli O157:H7; during summer months this proportion can be as high as $80 \%$ (Keen et al., 1999; R. O. Elder, unpublished data). These results collectively indicate that the prevalence of $E$. coli $\mathrm{O} 157: \mathrm{H} 7$ is much greater than was previously reported but also indicates that processing plants effectively reduce the spread of E. coli $\mathrm{O} 157: \mathrm{H} 7$ to finished carcasses (Elder et al., 2000). However, significant levels of $E$. coli O157:H7 still enter the abattoir within the live animal and enter the food chain, thus posing a risk to human health.

\section{Effects of Management Strategies on E. coli Populations}

Several epidemiological and risk assessment studies have been performed to identify cattle management strategies associated with an increased risk of $E$. coli O157:H7 fecal shedding (Dargatz et al., 1997; Hancock et al., 1998; Herriott et al., 1998). However, most of these studies were performed using less sensitive, culture-based methodologies rather than the more sensitive IMS technique; hence, the incidence rate in these studies was quite low, making it impossible to demonstrate management, or diet-dependent differences. Additionally, there have been conflicting correlations drawn because of the nature of these survey-based studies. Different dietary regimes and stages of production have been linked to $E$. coli $\mathrm{O} 157: \mathrm{H} 7$ shedding; however, the correlations have not been strong enough to lead to any new management or nutritional practices to reduce EHEC shedding.

Abrupt weaning practices have been shown to increase colonization with EHEC (Herriott et al., 1998); however, heifers older than 3 mo are the most commonly colonized group of cattle (Hancock et al., 1994; Hancock et al., 1997a; Mechie et al., 1997). The only dietary practice that significantly increased the risk of EHEC shedding among heifers was feeding corn silage (Herriott et al., 1998). The use of feed additives, such as monensin and lasalocid, demonstrated a marginally significant increase of EHEC shedding by heifers (Herriott et al., 1998). In adult cows, the only dietary variable that significantly impacted EHEC shedding was the inclusion of animal byproducts in the ration (Herriott et al., 1998). Other studies have found feeding whole cottonseed reduced E. coli O157 shedding (Hancock et al., 1994; Garber et al., 1995). Barley feeding was linked (albeit at a low correlation) to $E$. coli $\mathrm{O} 157: \mathrm{H} 7$ shedding (Dargatz et al., 1997), and in recent studies barley feeding was again associated with increased shedding of $E$. coli O157:H7 from experimentally infected feedlot cattle (Buchko et al., 2000b).

Ruminal and intestinal VFA concentrations have been suggested to limit the proliferation of $E$. coli (Wolin, 1969). Feed withdrawal or starvation results in decreased VFA concentration in the rumen and hindgut. Cattle can be transported long distances before slaughter, and feed may be withdrawn for a period of time from $6 \mathrm{~h}$ up to $48 \mathrm{~h}$. A fasting period has been shown to increase E. coli, Enterobacter, and total anaerobic bacterial populations throughout the intestinal tract (Buchko et al., 2000a; Gregory et al., 2000), increase Salmonella and E. coli populations in the rumen (Brownlie and Garu, 1967). Additionally fasting has been shown to induce "apparently $E$. coli (O157:H7) negative animals to become positive" (Kudva et al., 1995). Other studies have indicated that fasting made calves more susceptible to colonization by inoculated E. coli $\mathrm{O} 157: \mathrm{H} 7$ and demonstrated that fasted calves inoculated with $E$. coli $\mathrm{O} 157: \mathrm{H} 7$ shed greater populations than did calves fed normally (Cray et al., 1998). Other researchers have shown that cattle fasted for 48 h before slaughter contained significantly greater $E$. coli populations throughout the gut than did cattle fed hay or pasture (Gregory et al., 2000). In contrast, however, Harmon et al. (1999) demonstrated that fasting reduced ruminal VFA concentrations but did not significantly influence $E$. coli $\mathrm{O} 157: \mathrm{H} 7$ shedding.

Determination of dietary and management factors that influence EHEC shedding has been difficult using culture-based methodologies and surveys. The use of more sensitive molecular detection methods, such as IMS, in future studies may be able to elucidate subtle correlations between dietary factors and fecal shedding of EHEC. Additionally, direct, controlled experiments rather than general surveys, need to be conducted to determine the impact of specific dietary modifications on intestinal EHEC populations and shedding in cattle.

\section{Forage- vs Grain-Based Diet Effects on Fecal E. coli Populations}

Finishing beef and lactating dairy cattle in the United States are often fed high grain rations in order to improve performance and animal production (Huntington, 1997). Ruminant animals evolved to eat cellulosic plant material; however, the ruminal microbial population 
Table 1. Published reports of effects of diet on fecal Escherichia coli populations.

\begin{tabular}{|c|c|c|c|c|c|}
\hline Authors & Concentrate diet & $\begin{array}{l}E \text {. coli cfu/g } \\
\text { feces }\end{array}$ & Forage diet & $\begin{array}{l}E \text {. coli cfu/g } \\
\text { feces }\end{array}$ & $\begin{array}{l}\log _{10} \\
\text { impact }\end{array}$ \\
\hline Allison, 1975 & $\begin{array}{l}\text { Normal diet } \\
\text { Over-fed grain }\end{array}$ & $\begin{array}{l}8 \times 10^{6} \\
\text { coliforms } \\
1 \times 10^{10} \\
\text { coliforms }\end{array}$ & & & \\
\hline $\begin{array}{l}\text { Kudva, et al., } \\
1995\end{array}$ & $\begin{array}{l}100 \% \text { Alfalfa } \\
\text { pellets }\end{array}$ & $\begin{array}{l}\text { Shed O157:H7 } \\
\text { for } 4 \mathrm{~d}\end{array}$ & Sagebrush/bunchgrass & $\begin{array}{l}\text { Shed } 0157: \mathrm{H} 7 \\
\text { for } 15 \mathrm{~d}\end{array}$ & \\
\hline $\begin{array}{l}\text { Diez-Gonzalez } \\
\text { et al., } 1998\end{array}$ & $90 \%$ Concentrate & $8 \times 10^{7}$ & 100\% Timothy Hay & $3 \times 10^{4}$ & -3.5 \\
\hline $\begin{array}{l}\text { Jordan and } \\
\text { McEwen, } 1998\end{array}$ & $\begin{array}{l}44 \% \text { Dry corn } \\
7 \% \text { Dry Gluten } \\
\text { 7\% Distiller's } \\
\text { Dried Grains }\end{array}$ & $7 \times 10^{6}$ & $\begin{array}{l}50 \% \text { Corn silage } \\
50 \% \text { Alfalfa }\end{array}$ & $4 \times 10^{6}$ & -0.3 \\
\hline $\begin{array}{l}\text { Keen et al., } \\
1999\end{array}$ & $85 \%$ Concentrate & $\begin{array}{l}52 \% \text { shedding } \\
\text { O157:H7 }\end{array}$ & $100 \%$ Forage & $\begin{array}{l}\text { 18\% shedding } \\
\text { O157:H7 }\end{array}$ & \\
\hline $\begin{array}{l}\text { Hovde et al., } \\
1999\end{array}$ & $\begin{array}{l}62 \% \text { Barley/ } \\
19 \% \text { corn } \\
90 \% \text { Corn }\end{array}$ & $\begin{array}{l}7 \times 10^{6} \text { peak } \\
\text { ( } 4 \mathrm{~d} \text { of } \\
\text { shedding) }\end{array}$ & Alfalfa or Grass Hay & $\begin{array}{l}7 \times 10^{6} \text { peak } \\
\text { (39 or } 42 \mathrm{~d} \\
\text { shedding) }\end{array}$ & \\
\hline $\begin{array}{l}\text { Stanton and } \\
\text { Schutz, } 2000\end{array}$ & $85 \%$ Whole Corn & $3.2 \times 10^{7}$ & $\begin{array}{l}30 \% \text { Millet hay } \\
62 \% \text { whole corn }\end{array}$ & $1 \times 10^{6}$ & -1.2 \\
\hline $\begin{array}{l}\text { Scott et al., } \\
2000\end{array}$ & $\begin{array}{l}84 \% \text { Dry rolled } \\
\text { corn or } \\
41 \% \text { Dry rolled } \\
\text { corn } \\
45 \% \text { Wet corn } \\
\text { gluten }\end{array}$ & $\begin{array}{l}3 \times 10^{8} \\
5 \times 10^{8}\end{array}$ & $100 \%$ Alfalfa hay & $\begin{array}{l}1 \times 10^{7} \\
9 \times 10^{6}\end{array}$ & $\begin{array}{l}-1.2 \\
-1.6\end{array}$ \\
\hline $\begin{array}{l}\text { Buchko et al., } \\
2000 \mathrm{a}\end{array}$ & $80 \%$ Concentrate & $\begin{array}{l}\text { 5\% shedding } \\
\text { O157:H7 }\end{array}$ & $\begin{array}{l}100 \% \text { Alfalfa silage } \\
\text { (after } 48 \mathrm{~h} \text { fast) } \\
\text { Re-fed } 100 \% \\
\text { Alfalfa silage } \\
\text { (after } 48 \mathrm{~h} \text { fast) }\end{array}$ & $\begin{array}{l}\text { 5\% shedding } \\
\text { O157:H7 } \\
42 \% \text { shedding } \\
\text { O157:H7 after } \\
5 \mathrm{~d}\end{array}$ & \\
\hline
\end{tabular}

can degrade starch. Dietary starch is often enclosed by a protein (zein) matrix that protects the starch from ruminal microbial degradation and allows some of the starch to reach the intestine (Huntington, 1997). Ruminants have low pancreatic amylase activity; therefore, some of the dietary starch that escapes ruminal degradation passes through the small intestine to the cecum and colon, where it undergoes a secondary microbial fermentation (Huntington, 1997). Colonic and cecal starch fermentation by bacteria (including EHEC) produces VFA that can reduce the $\mathrm{pH}$ of the colonic digesta and inhibit $E$. coli. However, in spite of these harsh conditions, $E$. coli thrives in the intestinal tract of cattle fed high-grain rations (Allison et al., 1975; Diez-Gonzalez et al., 1998; Keen et al., 1998; Tkalcic et al., 2000; Scott et al., 2000; Stanton and Schutz, 2000).

Feeding grain to cattle has a pronounced effect on the ruminal microbial ecosystem and overall animal health (Russell and Rychlik, 2001). Studies have indicated that varying the forage-to-grain ratio in cattle rations can have a marked effect on shedding of $E$. coli O157:H7, but some studies have produced contradictory results (Table 1). Early studies indicated that a sudden decrease in hay intake increased $E$. coli popula- tions in cattle feces (Brownlie and Garu, 1967). Overfeeding of cattle with grain has been shown to cause a $2-\log _{10}$ increase in total coliform counts (Allison et al., 1975). Other studies using experimentally infected sheep found that a switch from an alfalfa pellet diet to a low quality forage diet increased $E$. coli $0157: \mathrm{H} 7$ shedding (Kudva et al., 1995). Kudva et al. (1997) found that sheep shifted from a 50:50 corn/alfalfa ration to a poor quality grass hay shed greater populations of $E$. coli $\mathrm{O} 157: \mathrm{H} 7$ than animals fed the corn/alfalfa ration.

In recent research, cattle fed a 90\% corn/soybean meal ration (feedlot-type ration) contained generic $E$. coli populations that were 100 -fold higher than cattle fed a 100\% good-quality hay (Timothy) diet (Diez-Gonzalez et al., 1998). The $E$. coli recovered from the feces of grain-fed cattle were 1000 -fold more resistant to an "extreme" acid shock that simulated passage through the human stomach than were $E$. coli from cattle fed only hay (Diez-Gonzalez et al., 1998). When cattle were abruptly switched from a $90 \%$ grain finishing ration to a $100 \%$ hay diet, fecal E. coli populations declined 1000fold, and the population of $E$. coli resistant to an extreme acid shock declined more than 100,000-fold within 5 d (Diez-Gonzalez et al., 1998). Although no $E$. 
coli $\mathrm{O} 157: \mathrm{H} 7$ were specifically detected in this study, it was previously demonstrated that $E$. coli $\mathrm{O} 157: \mathrm{H} 7$ could grow in VFA concentrations and at $\mathrm{pH}$ similar to those found in the colon of these grain-fed cattle (DiezGonzalez and Russell, 1997). Based on these results the authors suggested that feedlot cattle be switched from high grain diets to hay for $5 \mathrm{~d}$ before slaughter to reduce $E$. coli contamination entering the abattoir (Diez-Gonzalez et al., 1998).

The impact of brief periods of hay feeding on weight gain and carcass characteristics has not been examined in a systematic fashion, but research that has been recently performed indicates that it does not have a dramatic impact on carcass characteristics or final BW (Stanton and Schutz, 2000). When cattle were fed hay during this final period had lower DMI and lost an average of $2.2 \mathrm{lb} /$ heat per day (Stanton and Schutz, 2000). Hot carcass weight and dressing percentage were not significantly reduced by hay feeding (Stanton and Schutz, 2000). Hay feeding did not significantly impact carcass grades, quality parameters or cause dark cutters, but did significantly reduce total coliform counts as well as generic $E$. coli counts (Stanton and Schutz, 2000), but they were not reduced as greatly as those reported by Diez-Gonzalez et al. (1998). Neither $E$. coli O157:H7 populations, nor the acid resistance of $E$. coli were measured in this study (Stanton and Schutz, 2000). In another study, cattle fed hay for $48 \mathrm{~h}$ before transport to slaughter did not lose more weight during transport than fasted or pasture fed animals (Gregory et al., 2000).

Keen et al. (1999) also found that switching cattle from grain to hay caused a decrease in BW gain (approximately $1.25 \mathrm{lb} / \mathrm{hd}$ per day compared to controls). Through the use of modern molecular separation techniques, 200 cattle maintained on a grain ration were screened for natural E. coli O157:H7 infection and 53\% were found to be positive (Keen et al., 1999). When these cattle were divided into two groups and one was fed grain and the other abruptly switched to hay, $52 \%$ of the grain-fed cattle remained $E$. coli $\mathrm{O} 157: \mathrm{H} 7$ positive, but only $18 \%$ of the hay-fed cattle continued to shed $E$. coli O157:H7 (Keen et al., 1999). These results again indicated that feeding hay could impact the fecal shedding of $E$. coli and potentially reduce EHEC entry into the food chain.

The proposal of such a dietary switch provoked a great deal of scientific controversy (Hancock et al. 1999; Russell and Diez-Gonzalez, 1999; Russell et al., 2000) and led to several studies that have evaluated the effect of radical dietary changes on $E$. coli populations in cattle; however, these studies have also produced conflicting results (Table 1). When cattle were fed a high-concentrate diet and switched to a diet containing $50 \%$ corn silage and $50 \%$ alfalfa hay, generic $E$. coli counts decreased $0.3 \log$ in $4 \mathrm{~d}$ (Jordan and McEwen, 1998). Cattle fed an $80 \%$ barley ration, fasted for $48 \mathrm{~h}$, and switched to $100 \%$ alfalfa silage did not exhibit any change in E. coli O157:H7 shedding (Buchko et al., 2000a). However, when these same forage-fed animals were again fasted for $48 \mathrm{~h}$ and refed $100 \%$ alfalfa silage, the prevalence of $E$. coli O157:H7 shedding increased significantly (Buchko et al., 2000a).

Using cattle experimentally infected with $E$. coli O157:H7, Hovde et al. (1999) found that cattle fed hay shed $E$. coli O157:H7 longer than did grain-fed cattle (42 vs. 4 d, respectively), but concentrations of $E$. coli O157:H7 shed were similar between dietary regimes. Generic coliform bacteria from these hay-fed cattle were significantly more sensitive to acid shock than those from grain-fed cattle (Hovde et al., 1999), but the difference in acid shock sensitivity was not as great as that found by Diez-Gonzalez et al. (1998). Feeding a highgrain or -forage diet did not affect the acid resistance of $E$. coli $\mathrm{O} 157: \mathrm{H} 7$ isolated from these cattle; however, the researchers were unable to demonstrate sensitivity to an acid shock under their experimental conditions with an extreme shock-sensitive $E$. coli $\mathrm{O} 157: \mathrm{H} 7$ control strain (Hovde et al., 1999). However, differences in culture methodologies make direct comparisons between this study and previous studies impossible (Jarvis and Russell, 2001).

Other research groups have reported high grain of high forage diets did not affect the duration of shedding of fecal E. coli O157:H7 populations in experimentally inoculated calves; however, the calves that consistently shed the highest concentrations of $E$. coli $\mathrm{O} 157: \mathrm{H} 7$ were fed a high concentrate diet (Tkalcic et al., 2000). Ruminal fluid from steers fed a high-forage diet allowed greater proliferation of $E$. coli $\mathrm{O} 157: \mathrm{H} 7$ in vitro than did ruminal fluid from high-grain fed steers (Tkalcic et al., 2000), possibly due to differences in VFA concentrations. Acid shock experiments indicated that $E$. coli O157:H7 incubated in ruminal fluid taken from steers fed a high-grain diet was more acid shock-resistant than $E$. coli $\mathrm{O} 157: \mathrm{H} 7$ cells incubated in forage-fed ruminal fluid (Tkalcic et al., 2000). The authors stated that the ability of $E$. coli $\mathrm{O} 157: \mathrm{H} 7$ to become acid resistant could be one factor that influences fecal shedding in cattle (Tkalcic et al., 2000).

In a recent study, it was demonstrated that switching cattle from pasture to hay for $48 \mathrm{~h}$ before slaughter significantly reduced the $E$. coli burden throughout the gut (Gregory et al., 2000). The authors found that hay feeding increased intestinal Enterococci populations that are capable of inhibiting $E$. coli populations (Gregory et al., 2000). However, in this study the effects of high grain vs. forage diets were not examined, only the 
effects of fasting vs. pasture vs. hay-feeding (Gregory et al., 2000). Based on their results, the authors concluded, "the most effective way of manipulating gastrointestinal counts of $E$. coli was to feed hay" (Gregory et al., 2000).

Because switching feedlot cattle from grain to hay immediately before slaughter is not immediately practicable, feeding low-starch or high-fiber rations has been suggested as an alternative method to reduce $E$. coli O157:H7 shedding by reducing the starch load in the colon before slaughter (Scott et al., 2000). Fecal samples from cattle fed dry rolled corn, high-moisture corn, and wet corn gluten feed did not contain different populations of generic $E$. coli, or extreme acid-resistant $E$. coli during a limit-feeding period (Scott et al., 2000). However, cattle fed wet corn gluten ad libitum contained significantly higher concentrations of extreme acid resistant $E$. coli than cattle fed dry-rolled or high moisture corn (Scott et al., 2000). When these cattle were abruptly switched from a finishing diet to alfalfa hay, colonic $\mathrm{pH}$ increased, total $E$. coli populations decreased approximately 10 -fold, and acid-shock resistant $E$. coli populations were reduced by over $99 \%$ (Scott et al., 2000). These authors concluded "increased colonic $\mathrm{pH}$ was not associated with reduced populations of acid resistant $E$. coli" but "feeding hay for a short duration can reduce acid-resistant $E$. coli populations" (Scott et al., 2000). Again, these results emphasize that dietary manipulations (e.g., hay feeding) could be a powerful method to reduce $E$. coli/EHEC populations in cattle prior to harvest.

The cleanliness of animals entering holding pens at the abattoir is an important, and often overlooked factor that can impact the incidence of food-borne illness. Dried manure on the hide and hooves has been implicated as a primary route of contamination of carcasses via removal machinery (Grau, 1987; Hancock, 1999). However, Elder et al. (2000) demonstrated that there was a direct correlation between fecal populations of E. coli $\mathrm{O} 157: \mathrm{H} 7$ and carcass contamination levels. In a study by Gregory et al. (2000), when cattle arrived at the slaughter plant the hides of cattle fed hay for $48 \mathrm{~h}$ before transport were as clean as fasted cattle and were significantly cleaner than pasture-fed cattle (Gregory et al., 2000). Therefore these authors stated that feeding hay prior to transport to slaughter "offered the most advantages" (Gregory et al., 2000). Feeding strategies that result in cattle arriving at the abattoir with less "tag" on the hide at the time of slaughter can greatly enhance food safety.

\section{CONCLUSIONS}

The United States has the safest food supply in the history of the world; however, food-borne pathogenic bacteria are still significant threats to human health. Sanitation steps following slaughter effectively reduce carcass contamination with $E$. coli $\mathrm{O} 157: \mathrm{H} 7$, but preharvest intervention strategies offer avenues to reduce pathogen populations in food animals before they enter the food chain. Attempts to modify fecal shedding of $E$. coli $\mathrm{O} 157: \mathrm{H} 7$ through fasting and feeding poor-quality forages have been shown to increase shedding in cattle. However, abruptly switching cattle from a high grain ration to a high-quality hay-based diet has been shown to reduce generic $E$. coli and $E$. coli $\mathrm{O} 157: \mathrm{H} 7$ populations, but the magnitude of reduction has varied among studies. Switching all feedlot cattle in the United States from grain-based diets to hay prior to slaughter is not currently feasible, in spite of the potential benefits. Further research is needed to elucidate the mechanism by which forage-feeding impacts the microbial ecology of the bovine intestinal tract, including $E$. coli populations, so that economically viable dietary modifications can be devised and implemented.

\section{REFERENCES}

Acheson, D. W. K. 2000. How does Escherichia coli O157:H7 testing in meat compare with what we are seeing clinically? J. Food Prot. 63:819-821.

Allison, M. J., I. M. Robinson, R. W. Dougherty, and J. A. Bucklin. 1975. Grain overload in cattle and sheep: changes in microbial populations in the cecum and rumen. Am. J. Vet. Res. 36:181-185.

Armstrong, G. L., J. Hollingsworth, and J. G. Morris. 1996. Emerging foodborne pathogens: Escherichia coli O157:H7 as a model of entry of a new pathogen into the food supply of the developed world. Epidemiol. Rev. 18:29-51.

Bialaszewska, M., H. Schmidt, A. Liesegang, R. Prager, W. Rabsch, H. Tschape, A. Cizek, J. Janda, K. Blahova, and H. Karch. 2000. Cattle can be a reservoir of sorbitol-fermenting shiga toxin-producing Escherichia coli O157:H7-strains and a source of human diseases. J. Clin. Microbiol. 38:3470-3473.

Brownlie, L. E., and F. H. Grau. 1967. Effect of food intake on growth and survival of salmonellas and Escherichia coli in the bovine rumen. J. Gen. Microbiol. 46:125-134.

Buchko, S. J., R. A. Holley, W. O. Olson, V. P. J. Gannon, and D. M. Veira. 2000a. The effect of fasting and diet on fecal shedding of Escherichia coli O157:H7 by cattle. Can. J. Anim. Sci. 80:741-744.

Buchko, S. J., R. A. Holley, W. O. Olson, V. P. J. Gannon, and D. M. Veira. 2000b. The effect of different grain diets on fecal shedding of Escherichia coli O157:H7 by steers. J. Food Prot. 63:1467-1474.

Chapman, P. A., A. T. Cerdan Malo, C. A. Siddons, and M. Harkin. 1997a. Use of commercial enzyme immunoassays and immunomagnetic separation systems for detecting Escherichia coli O157:H7 in bovine fecal samples. Appl. Environ. Microbiol. 63:2549-2553.

Chapman, P. A., C. A. Siddons, A. T. Malo Cerdan, and M. A. Harkin. 1997b. A 1-year study of Escherichia coli O157:H7 in cattle, sheep, pigs, and poultry. Epidemiol. Infect. 119:245-250.

Chapman, P. A., C. A. Siddons, D. J. Wright, P. Norman, J. Fox, and E. Crick. 1993. Cattle as a possible source of verocytotoxinproducing $E$. coli 0157 infections in man. Epidemiol. Infect. 111:439-447.

Cizek, A., P. Alexa, I. Literák, J. Hamrik, P. Novák, and J. Smola. 1999. Shiga toxin producing Escherichia coli O157 in feedlot cattle and Norwegian rats from a large-scale farm. Lett. Appl. Microbiol. 28:435-439. 
Cray, J., W. C., T. A. Casey, B. T. Bosworth, and M. A. Rasmussen. 1998. Effect on dietary stress on fecal shedding of Escherichia coli O157:H7 in calves. Appl. Environ. Microbiol. 64:1975-1979.

Dargatz, D. A., S. J. Wells, L. A. Thomas, D. D. Hancock, and L. P. F. Garber. 1997. Factors associated with the presence of Escherichia coli $\mathrm{O} 157$ in feces of feedlot cattle. J. Food Prot. 60:466-470.

Davidson, C. M., and M. Taylor. 1978. Variability of $E$. coli levels in bovine feces and its implications on guidelines for ground beef. Can. Inst. Food Sci. Technol. J. 11:53.

Diez-Gonzalez, F., and J. B. Russell. 1997. The ability of Escherichia coli $\mathrm{O} 157: \mathrm{H} 7$ to decrease its intracellular $\mathrm{pH}$ and resist the toxicity of acetic acid. Microbiology 143:1175-1180.

Diez-Gonzalez, F., T. R. Callaway, M. G. Kizoulis, and J. B. Russell. 1998. Grain feeding and the dissemination of acid-resistant Escherichia coli from cattle. Science 281:1666-1668.

Doyle, M. P., T. Zhao, J. Meng, and S. Zhao. 1997. Escherichia coli O157:H7. Pages 171-191 in Food Microbiology: Fundamentals and Frontiers. M. P. Doyle, L. R. Beuchat, and T. J. Montville, ed. ASM Press, Washington, DC.

Drasar, B. S. 1974. Some factors associated with geographical variations in the intestinal microflora. Pages 187-196 in The Normal Microbial Flora of Man. F. A. Skinner and J. G. Carr, ed. Academic Press, London.

Drasar, B. S., and P. A. Barrow. 1985. Intestinal Microbiology. Pages 19-40 in A.S.F. Microbiol. ed. Washington, DC.

Elder, R. O., J. E. Keen, G. R. Siragusa, G. A. Barkocy-Gallagher, M. Koohmaraie, and W. W. Laegreid. 2000. Correlation of enterohemorrhagic Escherichia coli O157 prevalence in feces hides and carcasses of beef cattle during processing. Proc. Natl. Acad. Sci. 97:2999-3003.

Garber, L. P., S. J. Wells, D. D. Hancock, M. P. Doyle, J. Tuttle, J. A. Shere, and T. Zhao. 1995. Risk factors for fecal shedding of Escherichia coli O157:H7 in dairy calves. JAVMA 207:46-49.

Grau, F. H. 1987. Prevention of microbial contamination in the export beef abattoir. Pages 221-233 in Elimination of Pathogenic Microorganisms from Meat and Poultry. J. M. Smulders, ed. Elsevier Science Publishers, Amsterdam.

Gregory, N. G., L. H. Jacobson, T. A. Nagle, R. W. Muirhead, and G. J. Leroux. 2000. Effect of preslaughter feeding system on weight loss, gut bacteria, and the physico-chemical properties of digesta in cattle. N.Z. J. Agric. Res. 43:351-361.

Griffin, P. M. 1998. Epidemiology of shiga toxin-producing Escherichia coli infections in humans in the United States. Pages 1522 in Escherichia coli O157:H7 and Other Shiga Toxin-Producing E. coli Strains. J. B. Kaper and A. D. O’Brien, ed. ASM Press, Washington, DC.

Hancock, D. D., T. E. Besser, M. L. Kinsel, P. I. Tarr, D. H. Rice, and M. G. Paros. 1994. The prevalence of Escherichia coli O157:H7 in dairy and beef cattle in Washington state. Epidemiol. Infect. 113:199-207.

Hancock, D. D., T. E. Besser, D. H. Rice, D. E. Herriott, and P. I. Tarr. 1997a. A longitudinal study of Escherichia coli O157 in fourteen cattle herds. Epidemiol. Infect. 118:193-195.

Hancock, D. D., D. H. Rice, L. A. Thomas, D. A. Dargatz, and T. E. Besser. 1997b. Epidemiology of Escherichia coli 0157 in feedlot cattle. J. Food Prot. 60:462-465.

Hancock, D. D., T. E. Besser, and D. H. Rice. 1998. Ecology of Escherichia coli $\mathrm{O} 157: \mathrm{H} 7$ in cattle and impact of management practices. Pages 85-91 in Escherichia coli O157:H7 and Other Shiga ToxinProducing E. coli Strains. J. B. Kaper and A. D. O’Brien, ed. ASM Press, Washington, DC.

Hancock, D. D., T. E. Besser, C. Gill, and C. Hovde-Bohach. 1999. Cattle, hay and E. coli Science 284:51-52.

Harmon, B. G., C. A. Brown, S. Tkalcic, P. O. E. Mueller, A. Parks, A. V. Jain, T. Zhao, and M. P. Doyle. 1999. Fecal shedding and rumen growth of Escherichia coli O157:H7 in fasted calves. J. Food Prot. 62:574-579.

Herriott, D. E., D. D. Hancock, E. D. Ebel, L. V. Carpenter, D. H. Rice, and T. E. Besser. 1998. Association of herd management factors with colonization of dairy cattle by shiga toxin-positive Escherichia coli O157. J. Food Prot. 61:802-807.
Hornitzky, M. A., K. A. Bettelheim, and S. P. Djordjevic. 2000. The isolation of enterhaemorrhagic Escherichia coli O111:H- from Australian cattle. Aus. Vet. J. 78:636-637.

Hovde, C. J., P. R. Austin, K. A. Cloud, C. J. Williams, and C. W Hunt. 1999. Effect of cattle diet on Escherichia coli O157:H7 acid resistance. Appl. Environ. Microbiol. 65:3233-3235.

Hungate, R. E. 1966. The rumen bacteria. Pages 8-90 in The Rumen and Its Microbes. Academic Press, New York.

Huntington, G. B. 1997. Starch utilization by ruminants: from basics to the bunk. J. Anim. Sci. 75:852-867.

Jackson, S. G., R. B. Goodbrand, R. P. Johnson, V. G. Odorico, D. Alves, K. Rahn, J. B. Wilson, M. K. Welch, and R. Khakhria. 1998. Escherichia coli O157:H7 diarrhoea associated with well water and infected cattle on an Ontario farm. 120:17-20. Epidemiol. Infect.

Jarvis, G. N., and J. B. Russell. 2001. Differences in Escherichia coli culture conditions can have a large impact on the induction of extreme acid resistance. Curr. Microbiol. 43:215-219.

Jordan, D., and S. A. McEwen. 1998. Effect of duration of fasting and a short-term high-roughage ration on the concentration of Escherichia coli biotype 1 in cattle feces. J. Food Prot. 61:531-534.

Kaper, J. B., L. J. Gansheroff, M. R. Wachtel, and A. D. O’Brien. 1998 Intimin-mediated adherence of shiga toxin-producing Escherichia coli and attaching-and-effacing pathogens. Pages 148-156 in Escherichia coli O157:H7 and Other Shiga Toxin-Producing E. coli Strains. J. B. Kaper and A. D. O'Brien, ed. ASM Press,, Washington, DC.

Keen, J. E., G. A. Uhlich, and R. O. Elder. 1999. Effects of hayand grain-based diets on fecal shedding in naturally-acquired enterohemorrhagic $E$. coli (EHEC) $\mathrm{O} 157$ in beef feedlot cattle. 80th. Conference Research Workers in Animal Diseases, Nov. $7-$ 9, Chicago, IL.

Kudva, I. T., P. G. Hatfield, and C. J. Hovde. 1995. Effect of diet on the shedding of Escherichia coli O157:H7 shedding in a sheep model. Appl. Environ. Microbiol. 61:1363-1370.

Kudva, I. T., C. W. Hunt, C. J. Williams, U. M. Nance, and C. J. Hovde. 1997. Evaluation of dietary influences on Escherichia coli O157:H7 shedding by sheep. Appl. Environ. Microbiol. 63:3878-3886.

Lin, J., M. P. Smith, K. C. Chapin, H. S. Baik, G. N. Bennett, and J. W. Foster. 1996. Mechanisms of acid resistance in enterohemorrhagic Escherichia coli. Appl. Environ. Microbiol. 62:3094-3100.

Mainil, J. 1999. Shiga/Verocytotoxins and Shiga/verotoxigenic Escherichia coli in animals. Vet. Res. (Paris) 30:235-257.

Martens, M. H. 2000. Debunking the industrial agriculture myth that organic foods are more likely to be carriers of dangerous bacteria such as $E$. coli $\mathrm{O} 157: \mathrm{H} 7$ or plant fungus such as fuminosin. Available at: http://www.purefood.org/Organic/ecolimyths.cfm. (Accessed 10 July 2001).

Mead, P. S., L. Slutsker, V. Dietz, L. F. McCaig, J. S. Bresee, C. Shapiro, P. M. Griffin, and R. V. Tauxe. 1999. Food-related illness and death in the United States. Emerg. Infect. Dis. 5:607-625.

Mechie, S. C., P. A. Chapman, and C. A. Siddons. 1997. A fifteen month study of Escherichia coli O157:H7 in a dairy herd. Epidemiol. Infect. 118:17-25.

Midgley, J., N. Fegan, and P. Desmarchelier. 1999. Dynamics of shiga toxin-producing Escherichia coli (STEC) in feedlot cattle. Lett. Appl. Microbiol. 29:85-89.

O'Brien, A. D., and J. B. Kaper. 1998. Shiga toxin-producing Escherichia coli: Yesterday, today and tomorrow. Pages 1-11 in Escherichia coli $\mathrm{O} 157: \mathrm{H} 7$ and Other Shiga Toxin-Producing E. coli Strains. J. B. Kaper and A. D. O'Brien, ed. ASM Press, Washington, DC.

Paton, A. W., R. M. Ratcliff, R. M. Doyle, J. Seymour-Murray, D. Davos, J. A. Lanser, and J. C. Paton. 1996. Molecular microbiological investigation of an outbreak of hemolytic uremic syndrome caused by dry fermented sausage contaminated with Shiga-like toxin producing Escherichia coli. J. Clin. Microbiol. 34:1622-1627.

Pelan-Mattocks, L. S., M. E. Kehrli, T. A. Casey, and J. P. Goff. 2000. Fecal shedding of coliform bacteria during the periparturient period in dairy cows. Am. J. Vet. Res. 61:1636-1638. 
Pruimboom-Brees, I. M., T. W. Morgan, M. R. Ackermann, E. D. Nystrom, J. E. Samuel, N. A. Cornick, and H. W. Moon. 2000. Cattle lack vascular receptors for Escherichia coli O157:H7 Shiga toxins. Proc. Nat. Acad. Sci. (USA) 97:10325-10329.

Rasmussen, M. A., W. C. Cray, T. A. Casey, and S. C. Whip. 1993. Rumen contents as a reservoir of enterohemorrhagic Escherichia coli. FEMS Microbiol. Lett. 114:79-84.

Riley, L. W., R. S. Remis, S. D. Helgerson, H. B. McGee, J. G. Wells, B. R. Davis, R. J. Hebert, E. S. Olcott, L. M. Johnson, N. T. Hargrett, P. A. Blake, and M. L. Cohen. 1983. Hemorrhagic colitis associated with a rare Escherichia coli serotype. N. Engl. J. Med. 308:681-685.

Russell, J. B., and F. Diez-Gonzalez. 1999. Cattle, hay and E. colithe response. Science 284:51-52.

Russell, J. B., F. Diez-Gonzalez, and G. N. Jarvis. 2000. Effects of diet shifts on E. coli in cattle. J. Dairy Sci. 83:863-873.

Russell, J. B., and J. L. Rychlik. 2001. Factors that alter rumen microbial ecology. Science 292:1119-1122.

Schurman, R. D., H. Hariharan, S. B. Heaney, and K. Rahn. 2000. Prevalence and characteristics of Shiga toxin-producing Escherichia coli in beef cattle slaughtered on Prince Edward Island. J. Food Prot. 63:1583-1586.

Scott, T., C. Wilson, D. Bailey, T. Klopfenstein, T. Milton, R. Moxley, D. Smith, J. Gray, and L. Hungerford. 2000. Influence of diet on total and acid resistant $E$. coli and colonic pH. 2000 Nebraska Beef Rep. 39-41.

Stanton, T. L., and D. Schutz. 2000. Effect of switching from high grain to hay five days prior to slaughter on finishing cattle performance. Colorado State Univ. Research Report. Ft. Collins, CO.

$\mathrm{Su}, \mathrm{C}$., and L. J. Brandt. 1995. Escherichia coli O157:H7 infection in humans. Ann. Intern. Med. 123:698-714.
Tilden, J., W. Young, A. McNamara, C. Custer, B. Boesel, M. LambertFair, J. Majkowski, D. Vugia, S. B. Werner, J. Hollingsworth, and J. G. Morris. 1996. A new route of transmission for Escherichia coli: infection from dry fermented salami. Am. J. Public Health 86:1142-1145.

Tkalcic, S., C. A. Brown, B. G. Harmon, A. V. Jain, E. P. O. Mueller, A. Parks, K. L. Jacobsen, S. A. Martin, T. Zhao, and M. P. Doyle. 2000. Effects of diet on rumen proliferation and fecal shedding of Escherichia coli O157:H7 in calves. J. Food Prot. 63:1630-1636.

USDA:APHIS. 1997. An update: Escherichia coli O157:H7 in humans and cattle. CEAH, Fort Collins, CO.

USDA:ERS. 2001. Estimated annual costs due to selected food-borne pathogens. Available at: http://www.ers.usda.gov/Emphases/SafeFood/features.htm\#start. (Accessed 10 July 2001.)

Waterman, S. R., and P. L. C. Small. 1998. Acid-sensitive enteric pathogens are protected from killing under extremely acidic conditions of $\mathrm{pH} 2.5$ when they are inoculated onto certain food sources. Appl. Environ. Microbiol. 64:3882-3886.

Wells, G., L. D. Shipman, K. D. Greene, E. G. Sowers, J. H. Green, D. N. Cameron, F. P. Downes, M. L. Martin, P. M. Griffin, S. M. Ostroff, M. E. Potter, R. V. Tauxe, and I. K. Wachsmuth. 1991. Isolation of Escherichia coli $\mathrm{O} 157: \mathrm{H} 7$ and other shiga-like-toxin producing $E$. coli from dairy cattle. J. Clin. Microbiol. 29:985-989.

Wolin, M. J. 1969. Volatile fatty acids and the inhibition of Escherichia coli growth by rumen fluid. Appl. Microbiol. 17:83-87.

Zhao, T., M. P. Doyle, J. Shere, and L. Garber. 1995. Prevalence of enterohemorrhagic Escherichia coli O157:H7 in a survey of dairy herds. Appl. and Environ. Microbiol. 61:1290-1293.

Zschöck, M., H. P. Hamann, B. Kloppert, and W. Wolter. 2000. Shigatoxin-producing Escherichia coli in faeces of healthy dairy cows, sheep and goats: prevalence and virulence properties. Lett. Appl. Microbiol. 31:203-208. 